International Journal of Linguistics, Literature and Translation (IJLLT)

ISSN: 2617-0299 (Online); ISSN: 2708-0099 (Print)

DOI: 10.32996/ijllt

Website: https://al-kindipublisher.com/index.php/ijllt

\title{
The Pragmatics of Civility in Prince Harry's Exit Speech
}

Prof. Fareed Hameed Al-Hindawi ${ }^{1}$, and Asst. Prof. Nesaem Mehdi Al-Aadili*2

${ }^{1}$ Professor, University of Babylon, Department of English, College of Education for Human Sciences, Iraq

${ }^{2}$ Assitant Professor, University of Babylon, Department of English, College of Education for Human Sciences, Iraq

Corresponding Author: Nesaem Mehdi Al-Aadili, E-mail: nasaem_rose_i@yahoo.com

ARTICLE INFORMATION

Received: September 09, 2020

Accepted: October 15, 2020

Volume: 3

Issue: 10

DOI: 10.32996/ijllt.2020.3.10.10

\section{KEYWORDS}

Civility, pragmatics, exit speech, speech acts, politeness, Grice maxims

\section{ABSTRACT}

Civility is a widespread phenomenon in societies as it has its own place as one of the social values of humanity. In this regard, civility is conceived of as the act of showing regards for others through civilized verbal behaviour. However, civility is much more than that since it is viewed as the baseline of respect people owe to each other in public life. Generally speaking, civility prevails in religious contexts; nevertheless, it can be investigated in other contexts. Accordingly, the present study purports to set itself this task through concerning itself with the investigation of civility in a context other than the religious one. Precisely, it is intended to scrutinize this linguistic phenomenon in a speech by Prince Harry of Britain (the Duke of Sussex) with the aim of revealing the strategies through which civility is pragmatically realized. The data is purposefully chosen since Prince Harry is described as being civil and courteous. To achieve the aim of the study, the relevant literature on civility is surveyed and a model is developed for the purpose of pragmatically analyzing the data under perusal and coming out with certain findings.

\section{The Concept of Civility}

Civility can be defined as the act of showing regards for others by being polite; it is the act of exhibiting kindness and good manners to others in verbal interaction. In other words, civility is being friendly, courteous, and nice to others in verbal interaction. Merriam Webster dictionary defines civility as civilized conduct, especially courtesy or politeness, or a polite act or expression.

Civility can also be conceived of as an individual act or manner of behaving which conforms to social conventions of propriety. Synonyms of the term are amenity, attention, courtesy, formality, politeness, and reasonability. Civility is sometimes taken to mean as simply being polite but it is, in fact, more than that since it is the base of respect that we owe one another in public life. For Calhoun (2000: 253), genuine civility involves "a critical moral point of view about what really counts as kindness, respect, tolerance and consideration of others' feelings, among other things".

Fyfe et al. (2006, p. 855) make a distinction between proximate civility and diffuse civility. The former is often equated with politeness in interaction, while the latter involves a broader spectrum of behaviours which impact on others even in their absence. Thus, Peck (2002, p. 361) mentions that civility is a broad concept since it requires not only respect but also sacrifice, generosity, trust, duty, morality, self-restraint, fair, among others.

Smith and Bressler (2013, p. 455) and Billante and Saunders (2002, p. 33) mention that civility includes: (1) consideration of others which means "showing respect towards others, good manners, or being polite", and (2) consideration of self which means that discourse involves self-control and self regulation including thoughtful consideration of what one says and what one promotes, especially curtaining one's own immediate self interest when appropriate. Accordingly, Zerilli (2014, p. 114) defines civility as both "a certain way of caring for oneself and caring for others". Zerilli's definition of civility is adopted in this study.

K C AL-KINDI CENTER

R D FOR RESEARCH AND

$\mathbf{R}$ D DEVELOPMENT

Your gateway to world-class research
Published by Al-KindiCenter for Research and Development. Copyright (c) the author(s). This is an open access article under CC BY license (https://creativecommons.org/licenses/by/4.0/) 


\section{What Characterizes Civil Discourse?}

Civil discourse is described as the language of dispassionate objectivity that requires respect of the other participant. This type of discourse entails modesty and appreciation for the others and averts hostility, direct antagonism, or excessive persuasion (Kenneth, 2001, pp. 71-5). Civil discourse, thus, is characterized by being truthful, productive, and audience-based. Moreover, it is characterized by formality. It is important since it is intended to support people live peacefully in civil society, even if they may disagree with one another.

Civil discourse assists people preserve their relationships with other people (whether their families, friends, and neighbours) ensuring that they have robust ties across points of difference. It helps them clarify those areas upon which they disagree. It also signals regards for the feelings and concerns of other people.

\section{The Pragmatics of Civility}

Pragmatics, as a branch of linguistics, is simply defined as "the study of language use" (Levinson, 1983: 5). It is primarily interested not only in the meaning of the words of the talk, but also how human beings can get from what is said in words to the communicative purpose beyond the words of any piece of talk (LoCastro, 2012, p. 5). Pragmatics, then, prioritizes the communicative purpose of a speaker's talk as a core feature as the speaker's cognitive decisions are made on the basis of what the message intends to communicate (ibid.).

Thus, pragmatics concerns speaker meaning, specifically deriving the intended communicative message from what is said in a particular context. It involves the study of a variety of topics including speech acts, implicature, persuasion, and politeness, among others.

As for civility, civil discourse can be studied pragmatically since it is full of pragmatic strategies that realize it. These could include speech acts, politeness strategies, and abiding by the maxims, among others. This will be the topic of discussion in the next sub-sections.

\subsection{Civility in Relation to Speech Acts}

Speech acts, a theory proposed by Austin (1962) and developed by Searle (1969), are defined as "actions performed via utterances". Accordingly, to utter something is to do something. The theory of speech acts, then, is inherently a pragmatic theory since it involves an intention on the part of the speaker and an inference on the part of the hearer.

To perform a speech act is to perform three acts simultaneously: a locutionary act, an illocutionary act, and a perlocutionary act. The locutionary act has to do with what is said; the illocutionary act adds in the intention of the speaker regarding what act he intends to perform by means of making that utterance; the perlocutionary act is what is actually achieved by means of the speech act having an effect on the person being addressed (this effect could be on the thoughts, feelings, or actions of the addressee or others (Biner, 2013, pp. 186-7).

Speech acts can be direct or indirect. A direct speech act is that whose illocutionary force is the canonical illocutionary force for that form, an indirect speech act, by contrast, is that in which there is a mismatch between the linguistic form and the illocutionary force, that is, the illocutionary force in these cases is something other than the force canonically associated with that form (ibid, p. 192).

Civil speakers use various speech acts which are inherently polite. These could include: (1) acknowledging others, (2) praising others (i.e., giving others a sense of their own worth and praising their accomplishment), (3) asserting others' positive values, (4) thanking, (5) apologizing earnestly (i.e., regretting the negative impact one has made), (6) expressing gratitude what helps ameliorate a possible occasion of conflict.

\subsection{Civility in Relation to Politeness}

Mutz $(2015$, p. 7) argues that civility is closely related to politeness since politeness is a means of displaying respect. Yet, in spite of this close relationship between civility and politeness, the term civility is not widely mentioned in researches on politeness.

Papacharissi (2004, pp. 259-60) mentions that civility and politeness are frequently used interchangeably. She confirms that politeness is "etiquette-related", whereas civility is "respect for the collective traditions of democracy". Put differently, civility is broader than politeness since politeness refers to interaction that flows smoothly, whereas civility also involves interaction that fosters democratic goals. 
According to Stryker et al. (2016, p. 538), civility and politeness are used synonymously in everyday parlance. Escandell-Vidal $(1998$, p. 46) sees civility "as one of the basic dimensions of politeness based on culture-specific norms". In the same vein, Haugh (2013, p. 231) argues that "politeness is often regarded as a benchmark of civility".

Smith and Bressler (2013, p. 455) mention that civility is closely related to politeness in that it is usually measured and evaluated by looking at the politeness of speech and adherence to democratic norms. One difference is that politeness is broadly defined in terms of showing consideration for others, while civility is more frequently defined as showing respect for self and others.

Civil speakers prone to using various politeness strategies, whether positive or negative politeness strategies, such as inclusive "we", titles, avoid disagreement, avoid challenging others, token disagreement, hedging opinions, and the like.

\subsection{Civility in Relation to Grice's Maxims}

Civil speakers involved in any type of speech are cooperative since they want to make their intent patent. Thus, cooperation is a necessary factor that requires the civil converser not to trick, confuse, or withhold relevant information from the other so as to make sense of what is said; otherwise, he is said to generate implicatures which are additional conveyed meanings.

Cooperation can be stated as a cooperative principle. Following Grice (1989, pp. 26-7), this principle reads as follows: "make your conversational contribution such as is required, at the stage at which it occurs, by the accepted purpose or direction of the talk exchange in which you are engaged". The cooperative principle is elaborated in four sub-principles called maxims which civil speakers abide by. These are the following:

\section{Maxim of Quantity}

- Make your contribution as informative as is required (for the current purposes of the exchange).

- Do not make your contribution more informative than is required.

Thus, for the sake of being informative, the speaker has to say as much as what he needs to say, no more no less.

\section{Maxim of Quality}

- Do not say what you believe to be false.

- Do not say that for which you lack adequate evidence.

Accordingly, this maxim requires true contribution on the part of the speaker. It deals with the quality of the information given by the speaker to the listener.

\section{Maxim of Relation}

This maxim requires making relevant contributions.

\section{Maxim of Manner (Be perspicuous)}

- Avoid obscurity of expression.

- Avoid ambiguity

- Be brief by avoiding unnecessary prolixity

- Be orderly.

Briefly, these maxims specify what the converser has to do in order to converse in a maximally efficient, rational, cooperative way. This involves providing an appropriate amount of information, telling the truth, being relevant, and trying to be as clear as possible.

\section{Model of Analysis}

A model is developed as a basic apparatus for analyzing instances of civility in Prince Harry's exit speech. The developed model focuses on revealing the strategies employed by Prince Harry to pragmatically realize civility in his speech. These strategies include speech acts, politeness strategies, and abiding by the maxims. The model could be diagramed as follows: 


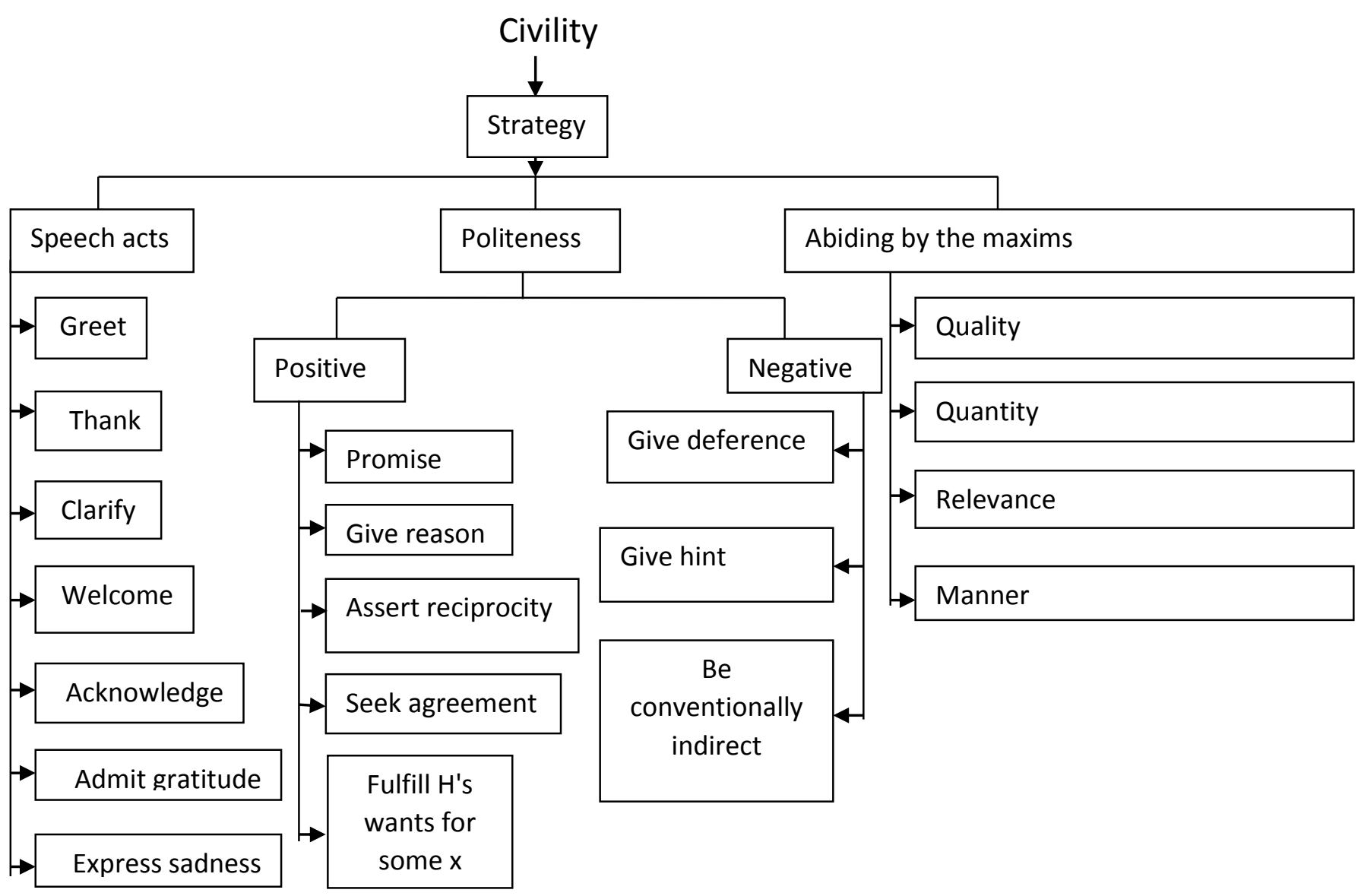

\section{Data Description}

The data of the study represents a speech delivered by Prince Harry after royal split. The speech is characterized by various instances where civility prevails. Thus, it is chosen as the data of the present study.

\section{Data Analysis}

In this section, illustrative examples from the data are analyzed according to the model developed for this purpose. The examples are analyzed in relation to the items of the model:

\section{Abiding by the Maxims}

In his speech, Prince Harry abides by Grice's maxims. He carefully observes the four maxims, that is, quantity, quality, manner, and relation. As far as the maxim of quantity is concerned, Prince Harry presents the required amount of information; he tries to be as informative as he can, and gives as much information as is needed, no more no less than is required. As regards the maxim of quality, Prince Harry, through his speech, tries to be truthful through giving information which is neither false nor fishy; rather, he presents information that is supported by evidence.

Moreover, Prince Harry observes the maxim of relation through being relevant and saying things that are pertinent to the purpose of his speech in which he clarifies the reason behind his and Meghan's decision to split royal life and promises people that he will not disavow his responsibilities towards them, particularly his work and commitment for AIDS and HIV charity Sentebal. With reference to the maxim of manner, Prince Harry tries to be clear, brief, and orderly. He presents the items of his speech in an orderly manner without any obscurity or ambiguity since he aims to clarify and justify various important matters in his speech.

Yet, Prince Harry violates the maxim of manner (be perspicuous) two times in his speech for the sake of politeness and to avoid saying something which might hurt others' feelings. Once, in saying "I would step my family back from all I have ever known, to take a step forward into what I hope can be a more peaceful life", the Prince may implicate that his royal life is not peaceful. 
The second violation of manner maxim (i.e., clarity) is evident in saying "You have looked out for me for so long, but the media is a powerful force" wherein the Prince does not clarify what he means by "the media is a powerful force".

\section{Speech Acts}

Prince Harry exploits various speech acts which are inherently polite to realize civility in his speech. The following are instances of these speech acts:

a- Greeting "Good evening"

b- Thanking "Thank you for being here for Sentebale, a charity me and Prince Seeiso created back in 2006", and "Thank you for giving me the courage to take this next step".

c- Acknowledging "The UK is my home and a place that I love", and "I have grown up feeling support from so many of you, and I watched you welcomed Meghan with open arms as you saw me find the love and happiness that I had hopped for all my life"

d- Expressing sadness "It brings me great sadness that it has come to this"

e- Clarifying "The decision that I have made for my wife and I to step back is not one I made lightly. It was so many months of talks after so many years of challenges", "What I want to make clear is we're not walking away, and we aren't certainly walking away from you", "Stuck by the hardship and challenges so many children faced, and with the support of local partners, we set up Sentebale two years later. The word Sentebale means "forget me not" in a Sesotho and also serves as a memory of both Prince Seeiso's mother as well as my own", and "Since the beginning, we have developed a series of programs and created the purpose built Mamahato centre to help a generation of children break through the stigma that is allowing the HIV epidemic to thrive"

f- Admitting gratitude (feeling grateful) "When I lost my mum 23 years ago, you took me under your wing", and "I am incredibly grateful to her and the rest of my family for the support they have shown Meghan and I over the last few month"

g- Welcoming "Welcome to Richard's garden..minus the fountain"

\section{Politeness Strategies}

Prince Harry exploits various politeness strategies, whether positive or negative, in order to make his speech civil. These strategies are:

\section{Positive politeness strategies}

a. Fulfill hearers' want for some $x$ : In telling the listeners "I want you to hear the truth from me, as much as I can share...", Prince harry fulfills their need of aspiring to hear the reason behind their decision to split royal life.

b. Promise: Prince Harry promises people that he will remain as they know him and will not change and the UK will remain his home and the place he loves most "The UK is my home and a place that I love. That will never change", and "It has been our privilege to serve you, and we will continue to lead a life of service". Promising is also evident in "I will always have the utmost respect for my grandmother, my Commander-in-chief" and "I will continue to be the same man who holds his country dear and dedicates his life to supporting the causes, charities and military communities that are so important to me".

c. Assert reciprocity: In various instances, Prince Harry asserts reciprocity with the listeners; he asserts that he knows them very well and trusts them and at the same time they know him and trust him. This is evident in "I also know you have come to know me well enough over all these years" and "Our collective support for each other can be more powerful because this is so much bigger than just us".

d. Give reason: Vindicating certain behaviour through giving reasons is a positive politeness strategy intended for the purpose of making speech civil. Prince harry gives the reason behind his decision to step back saying "There really was no other option".

e. Seek agreement through repetition: Through repeating the idea that they are not walking away, Prince Harry tries to seek people's agreement to cater for his decision of stepping back royal life "What I want to make clear is we're not walking away, and we certainly aren't walking away from you"

\section{Negative politeness strategies}

a. Give deference: Prince Harry shows himself as a civil speaker through using titles "the Queen", "Commander-in-chief", and "Prince". 
b. Give hint: In saying "I would step my family back from all I have ever known, to take a step forward into what I hope can be a more peaceful life", Prince Harry gives a hint that their royal life is not peaceful. For the sake of being polite, Prince harry avoids saying this directly.

c. Be conventionally indirect: Prince Harry says "The media is a powerful force" without stating why. Thus, he is indirect so as to keep his speech civil.

\section{Conclusions}

First, civility in the chosen data involves two facets: considerations of the others wherein Prince Harry shows respect, good manners, and politeness towards others as well as consideration of self since his speech is characterized by self-control and regulation including thoughtful consideration of what he says and what he tries to promote, especially curtaining his own immediate interest when appropriate (i.e., his decision to split royal life is associated with his hope to live peacefully). Selfrespect is evident in various instances in the speech as in "We will continue to lead a life of service" wherein the prince uses the pronoun "we" to refer to himself instead of "I". Second, civility can be realized pragmatically. This is crystallized by Prince Harry's use of various pragmatic strategies to realize civility in his speech. These strategies include various speech acts such as greeting, thanking, and acknowledging among others, abiding by the maxims as well as different politeness strategies, whether positive or negative, which are considered as a benchmark of civility. Third, civility requires trust and duty. Both are reflected in the analyzed speech wherein Prince Harry admits his duties towards UK, the Queen, and the people and indicates interplay trust between people and himself.

\section{Suggestion for further research}

A study of civility in religious texts is possible. Religious texts include the holy Qur'an, the Bible, speeches by infallible imams and religious sermons.

\section{References}

[1] Billante, N. and Saunders, P. (2002). Why Civility Matters. Policy 18,(3), 32-6.

[2] Calhoun, C. (2000). The Virtue of Civility. Philosophy and Public Affairs 29(3), 251-75.

[3] Carter, S. L. (1998). Civility: Manners, Morals, and the Etiquette of Democracy. New York: Basic Books.

[4] Escandel-Vidal, V. (1998). Politeness: A Relevant Issue for Relevance Theory. Revista Alicantina de Studios Ingleses 11, $45-57$.

[5] Fyfe, N., Banister, J., and Kearns, A. (2006). (In)civility and the City. Urban Studies 43 (5/6), 853-61).

[6] Grice, H. P. (1989). Studies in the Way of Words. Harvard: Harvard University Press.

[7] Haugh, M. (2013). Im/politeness, Social Practice and the Participation Order. Journal of Pragmatics 58, 52-72.

[8] Mutz, D. C. (2015). In-your-face Politics: The Consequences of Uncivil Media. Princeton: Princeton University Press.

[9] Papacharissi, Z. (2004). Democracy Online: Civility, Politeness, and the Democratic Potential of Online Political Discussion Groups. New Media and Society 6 (2), 259-283.

[10] Peck, D. L. (2002). Civility: A Contemporary Context for a Meaningful Historical Concept. Sociological Inquiry 72, 358-75. D 10.1111/1475-682x.00022.

[11] Smith, E. S. and Bressler, A. (2013). Who Taught you to Talk like that? The University and Online Political Discourse, Journal of Political Science Education 9 (4), 453-74.

[12] Stryker, R., Conway, B. A, and Danielson, T. J. (2016). What is Political Incivility? Communication Monographs 83 (40), 535-56.

[13] Zerilli, L. M. G. (2014). Against Civility: A Feminist Perspective. In: Sarat, A. (ed.), Civility, Legality, and Justice in America. Cambridge: Cambridge University Press, pp. 107-131. 